University of Nebraska - Lincoln

DigitalCommons@University of Nebraska - Lincoln

Publications, Agencies and Staff of the U.S.

Department of Commerce

U.S. Department of Commerce

2009

\title{
Paedomorphic Ossification in Porpoises with an Emphasis on the Vaquita (Phocoena sinus)
}

\author{
Liliana Mellor \\ East Carolina University \\ Lisa Noelle Cooper \\ Northeastern Ohio Universities, I.noelle.cooper@gmail.com \\ Jorge Torre \\ Comunidad y Biodiversidad, A.C. Boulevard Agua Marina 297, entre Jaiba y Tiburón Col. Delicias, \\ Guaymas, Sonora, C.P. 85420, Mexico \\ Robert L. Brownell Jr. \\ NOAA Southwest Fisheries Science Center, rlbcetacea@aol.com
}

Follow this and additional works at: https://digitalcommons.unl.edu/usdeptcommercepub

Part of the Environmental Sciences Commons

Mellor, Liliana; Cooper, Lisa Noelle; Torre, Jorge; and Brownell, Robert L. Jr., "Paedomorphic Ossification in Porpoises with an Emphasis on the Vaquita (Phocoena sinus)" (2009). Publications, Agencies and Staff of the U.S. Department of Commerce. 67.

https://digitalcommons.unl.edu/usdeptcommercepub/67

This Article is brought to you for free and open access by the U.S. Department of Commerce at DigitalCommons@University of Nebraska - Lincoln. It has been accepted for inclusion in Publications, Agencies and Staff of the U.S. Department of Commerce by an authorized administrator of DigitalCommons@University of Nebraska - Lincoln. 


\title{
Paedomorphic Ossification in Porpoises with an Emphasis on the Vaquita (Phocoena sinus)
}

\author{
Liliana Mellor, ${ }^{1}$ Lisa Noelle Cooper, ${ }^{2,3}$ Jorge Torre, ${ }^{4}$ and Robert L. Brownell, Jr. ${ }^{5}$ \\ ${ }^{1}$ Department of Anatomy and Cell Biology, Brody School of Medicine at East Carolina University, \\ Greenville, NC 27834, USA \\ ${ }^{2}$ Department of Anatomy and Neurobiology, Northeastern Ohio Universities College of Medicine, \\ Rootstown, OH 44272,USA; E-mail: l.noelle.cooper@gmail.com \\ ${ }^{3}$ School of Biomedical Sciences, Kent State University, Kent, OH 44242, USA \\ ${ }^{4}$ Comunidad y Biodiversidad, A.C. Boulevard Agua Marina 297, entre Jaiba y Tiburón Col. Delicias, \\ Guaymas, Sonora, C.P. 85420, Mexico \\ ${ }^{5}$ NOAA Southwest Fisheries Science Center, 1352 Lighthouse Avenue, Pacific Grove, CA 93950, USA
}

\begin{abstract}
Heterochrony, the change in timing of developmental processes, is thought to be a key process shaping the numerous limb morphologies of tetrapods. Through a delayed offset in digit development, all cetaceans (i.e., whales, dolphins, and porpoises) have evolved supernumary phalanges (hyperphalangy). Moreover, some toothed cetaceans further alter digital morphologies by delayed endochondral and perichondral ossification of individual elements. In the harbor porpoise (Phocoena phocoena), these paedomorphic patterns have created poorly ossified phalangeal elements. However, no studies have addressed this morphology in other porpoise taxa. This study documents the timing of carpal and digital epiphyseal ossification in the poorly studied vaquita (Phocoena sinus) based on radiographs $(n=18)$ of known-age specimens. Patterns of vaquita manus ossification were compared between other porpoise and delphinid taxa. Adult vaquitas are paedomorphic in carpal, metacarpal, and digital development as they maintain a juvenile ossification pattern relative to that of other porpoise species of equivalent ages. Vaquitas also ossify fewer carpal elements as compared to other porpoise and some delphinid cetaceans, and ossification arrests relative to that of the harbor porpoise. Vaquitas also display sexual dimorphism as females reach a greater body size and display more ossified elements in the manus relative to their paedomorphic male cohorts.
\end{abstract}

Key Words: Phocoenidae, paedomorphosis, heterochrony, forelimb, sexual dimorphism, endochondral ossification, Phocoena, vaquita

\section{Introduction}

Changes in the timing of events during skeletal development have been a major source of morphological variation in the tetrapod body plan (e.g., Richardson, 1995; Richardson et al., 1997; Schlosser, 2001; Smith, 2003; Gomez et al., 2008). Moreover, one of the best studied systems of evolutionary and developmental biology is the tetrapod limb. Heterochrony, or a change in the timing of developmental processes (Smith, 2003), during early limb development and chondrogenesis of tetrapods has led to a wealth of morphological variation: for instance, the precocial development of forelimbs of marsupials (Smith, 2003; BinindaEmonds et al., 2007), the regenerative abilities of amphibian limbs (Galis et al., 2003), the precocial hindlimb development of frogs (Schlosser, 2001; Bininda-Emonds et al., 2007), the elongated digits of bats (Sears et al., 2006), and the supernumary phalanges in the digits of dolphins (Richardson \& Oelschläger, 2002). This study investigates the role of heterochrony in shaping the limb of the porpoise.

Cetaceans (i.e., whales, dolphins, and porpoises) evolved from terrestrial artiodactyls (Gingerich et al., 2001; Thewissen et al., 2001, 2007; Geisler \& Uhen, 2003) and their forelimb has shifted from an organ of terrestrial locomotion to a flipper that generates lift and aids in steering and braking. Compared to their terrestrial ancestors, cetacean forelimbs display unique morphological features that are associated with heterochronic shifts in forelimb development (Figure 1). Delayed carpal ossification in some cetaceans results in poorly ossified and sometimes completely cartilaginous elements in adult taxa. In addition, this delayed carpal ossification may create a block of cartilage that restricts movement and results in a stiff carpus (Figure 1c) (Howell, 1930). Changes in the timing 

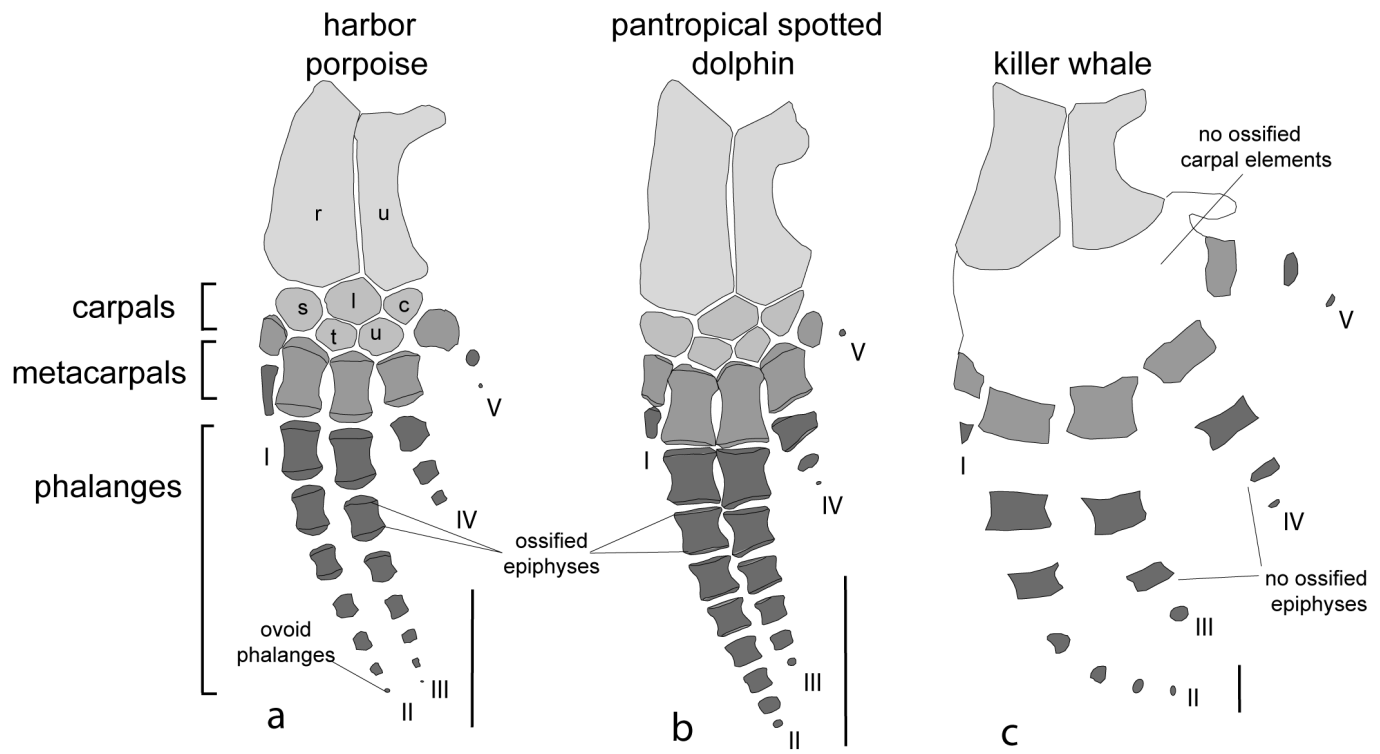

Figure 1. Adult forelimb morphologies of several odontocete cetaceans: (a) harbor porpoise (USNM 550312), (b) pantropical spotted dolphin (USNM 500837), and (c) killer whale (S-946; modified from Cooper et al., 2007b). The radius (r), ulna (ul), scaphoid (s), lunate (1), cuneiform (c), trapezoid (t), and unciform (u) are labelled. Roman numerals indicate digit number. The gray indicates ossified elements, while the white indicates cartilaginous elements. Scale bar is $5 \mathrm{~cm}$.

of ossification throughout development may generate adult limbs that resemble those of juveniles, called paedomorphosis. Paedomorphic patterns of endochondral ossification within the carpus are most pronounced in baleen whales (Flower, 1885), and the adult killer whale (Orcinus orca) (Figure 1c).

Another unique morphological feature in the manus of cetaceans is hyperphalangy (Figure 1) (Howell, 1930; Sedmera et al., 1997; Richardson \& Oelschläger, 2002; Fedak \& Hall, 2004). Recent descriptive embryological studies of the pantropical spotted dolphin (Stenella attenuata) found that hyperphalangy was generated due to the terminal addition of phalanges well into the fetal stages, indicative of a delayed offset (heterochrony) or developmental continuation of digital development (Richardson \& Oelschläger, 2002).

Porpoises (phocoenids) evolved a flipper that functions as a hydrofoil. Porpoises are the smallest cetaceans, and some have reported swimming speeds of approximately $1.5 \mathrm{~m} / \mathrm{s}$. Their broad flippers generate lift and drag, facilitating surfacing maneuvers (Smith et al., 1976). The harbor porpoise (Phocoena phocoena) flippers contribute to $18 \%$ of the total hydrodynamic drag, but they are only 4\% of the body area (Woodward et al., 2006). Empirical data on wild harbor porpoises have shown that the flippers are positioned into lift-generating orientations (symmetrical dorsal rotation of the leading edge of the flippers) just prior to surfacing, but during swimming maneuvers, the flippers are usually positioned against the body (Smith et al., 1976), thus reducing drag. Although data suggest that porpoise flippers function as a standard cetacean flipper, their anatomical structure and development are unique.

In addition to the changes in digital development associated with hyperphalangy, harbor porpoises also display heterochronic shifts in metacarpal and phalangeal ossification relative to small-bodied delphinid cetaceans (Figure 1a \& b). For instance, harbor porpoises delay perichondral ossification of phalangeal diaphyses, resulting in shape changes in proximal diaphyses that progress developmentally from ovoid, to deltoid (triangular), and finally to rectangular. Furthermore, a number of distal elements retain the paedomorphic condition of ovoid and/or deltoid shaped elements (Dawson, 2003). In addition to altered perichondral ossification, porpoises ossify fewer numbers of epiphyses compared to some delphinid cetaceans (Figure 1). The striped dolphin (Stenella coeruleoalba) ossifies the epiphyses of metacarpals I through IV as well as all proximal and mid-digit phalangeal epiphyses (Calzada \& Aguilar, 1996; DiGiancamillo et al., 1998). Unlike the striped dolphin, harbor porpoises fail to ossify the distal epiphysis of metacarpal I, and a greater number of phalangeal epiphyses lack ossification (Galatius et al., 2006).

Most phocoenids are also sexually dimorphic in their soft tissue and skeletal development 
(McLellan et al., 2002; Galatius et al., 2006). Female harbor porpoises grow more relative to males, achieving larger body sizes. Male harbor porpoises retain a juvenile limb proportiontheir limb skeletal development arrests around 6 y. Male harbor porpoises, therefore, reach sexual maturity sooner than females, but their skeletal morphologies are more paedomorphic (Galatius et al., 2006).

\section{Vaquita (Phocoena sinus)}

The vaquita (Phocoena sinus), the world's smallest cetacean, is endemic to the northern region of the Gulf of California (Sea of Cortez) and is currently listed as critically endangered with a population of approximately 150 individuals. It is threatened by accidental deaths in fishing gear (Brownell, 1983; Jaramillo-Legorreta et al., 2007; Morell, 2008). The population is inbred and has suffered a bottleneck-numbers have been low throughout their history (Taylor \& Rojas-Bracho, 1999; Rojas-Bracho et al., 2006).

Anatomy of the vaquita flipper has been documented in several studies (Figure 2) (Noble \& Fraser, 1971; Magatagan et al., 1984; OrtegaOrtiz, 1993, 2000; Torre-Cosio, 1995; VillaRamírez et al., 1996). Possibly as a result of the population's genetic homogeneity, a small extra digit (with up to four phalanges) is expressed as a fixed trait in the population (Ortega-Ortiz, 1993, 2000; Villa-Ramírez et al., 1996). This additional digit is enveloped in dense connective tissue and probably does not affect digit function; however, no functional studies have addressed its potential hydrodynamic effects. The vaquita is also exceptional in that it is the only porpoise to display only three ossified carpal elements as an adult.

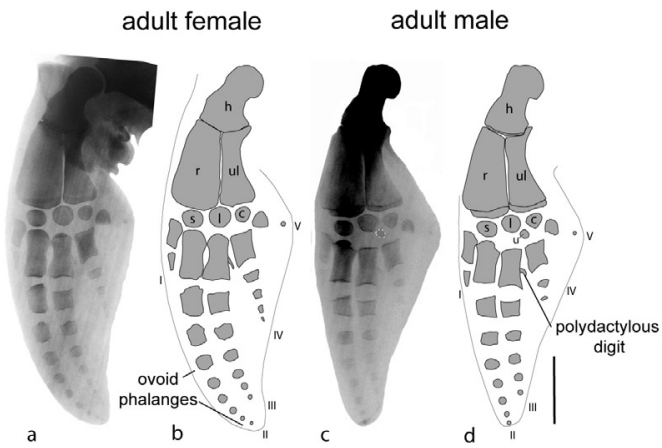

Figure 2. Adult forelimb morphology of a 13-mo female vaquita (ITESM 910313-1): (a) radiograph and (b) tracing; and a 9-mo-old male (ITESM 900421): (c) radiograph and (d) tracing. The radius (r), ulna (ul), scaphoid (s), lunate (l), and cuneiform (c) are labelled. Roman numerals indicate digit number; and the scale bar is $5 \mathrm{~cm}$.
Paedomorphosis has been documented in the adult vaquita skull relative to other phocoenids in that cranial elements are thin, display a greater number of foramina, lack ossification of some elements (i.e., squamosal), and sutures are poorly ankylosed (Barnes, 1985; Torre-Cosio, 1995). However, no studies have addressed paedomorphosis in vaquita appendicular components, nor has it been studied across a broad range of phocoenids (Dawson, 2003; Gol'din, 2004; Galatius et al., 2006).

Herein, we investigate patterns of manus ossification in the vaquita to determine if the vaquita displays carpal, metacarpal, and/or phalangeal morphologies consistent with paedomorphosis compared to other phocoenid and small-bodied delphinid taxa.

\section{Materials and Methods}

\section{Nomenclature}

We used the standard Nomina Anatomica Veterinaria (InternationalCommittee on Veterinary Gross Anatomical Nomenclature, 2005) for forelimb terminology. For orientation, the leading edge of the flipper is referred to as cranial and the trailing edge as caudal and the two main surfaces of the flipper are termed dorsal or palmar. The term digit is used when referring to only the phalanges that make up a finger, while the term manus is used when referring to the carpals, metacarpals, and phalanges (Figure 1). In a cranial-tocaudal direction, the proximal row of carpal elements are named the scaphoid (s), lunate (1), and cuneiform (c) (Figures $1 \& 2$ ). The two elements of the distal row are called the trapezoid $(\mathrm{t})$ and unciform (u) (Flower, 1885). The trapezium is lost in extant cetaceans by its fusion with metacarpal I, although metacarpal I frequently assumes the shape of a carpal element in odontocetes (Flower, 1885).

\section{Samples}

Disarticulated and unlabeled carpals, metacarpals, and phalanges are frequently preserved in museum osteological collections. Due to a lack of distinguishing characteristics and their similarity in size, it is nearly impossible to reliably distinguish between metacarpal and phalangeal elements, sequential elements of the same digit, or elements of different digits in disarticulated osteological specimens. Radiographs of cadaverous cetacean flippers offer a precise means of accurately counting the number of bony elements in the carpus and digits in situ. Osteological specimens were used only with articulated flippers.

Numbers of ossified carpal, metacarpal, and phalangeal elements and presence of ossified 
epiphyses were recorded for each specimen. A sample of phocoenid flipper radiographs and osteological specimens $(n=30)$ from the collections of the San Diego Natural History Museum (SDNHM), Smithsonian Institution (USNM), and Instituto Tecnológico y de Estudios Superiores de Monterey, Guaymas, Mexico (ITESM), and osteological specimens from the R. Natalie P. Goodall Foundation at the Museo Acatushún, Tierra del Fuego, Argentina (RNP) marine mammal collections were photographed (see Appendix for complete specimen list). The samples included radiographs of the vaquita $(n=18)$, Burmeister's porpoise ( $P$. spinipinnis, $n=1$ ), harbor porpoise $(n=1)$, and Dall's porpoise $(n=1)$. The osteological samples include Burmeister's porpoise $(n$ $=3$ ), the harbor porpoise ( $n=3$ as one specimen was also radiographed), the spectacled porpoise ( $P$. dioptrica, $n=2$ ), and the finless porpoise (Neophocaena phocaenoides, $n=2$ ).

\section{Age Determination}

Estimates of the age of most vaquita specimens were based on the numbers of growth layer groups (GLGs) within the decalcified, sectioned, and stained teeth based on known histological methods (Hohn et al., 1996). Each GLG is approximately equivalent to one calendar year of growth (Rosel et al., 2003).

\section{Observations of Epiphyseal Ossification and Ankylosis}

Patterns of metacarpal and phalangeal ossification and ankylosis were recorded for each flipper. Each diaphysis was assigned a stage of ossification and ankylosis following the staging criteria used in harbor porpoises (Galatius et al., 2006): Stage 0 unossified epiphysis; Stage 1, epiphysis ossified but not ankylosed to the diaphysis; Stage 2 , epiphysis initially ankylosed; Stage 3, progressing ankylosis; and Stage 4, complete ankylosis (Galatius et al., 2006).

\section{Results}

Carpus

The typical vaquita carpus displays three large cartilaginous anlage and sometimes a fourth, tiny anlagen in the proximal row and no anlage in the distal row (Figure $3 b \&$ e). These three large anlage are the site of ossification for three carpal elements-(1) scaphoid, (2) lunate, and (3) cuneiform - and the fourth tiny anlagen usually fails to ossify the pisiform (Figures $2 \& 3 e$ ). The three ossified carpal are ovoid shape into adulthood, and their borders are unarticulated (Figures $2 \&$ $3 \mathrm{e}$ ). Only two specimens (ITESM 850313-04-24, $134.5 \mathrm{~cm}$ total length; ITESM 900421, $142.2 \mathrm{~cm}$

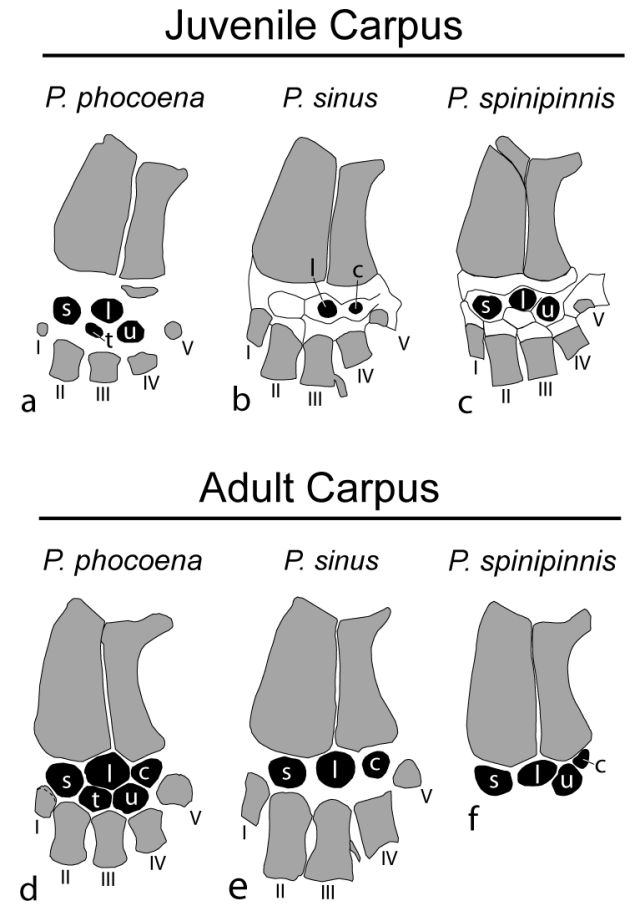

Figure 3. Ossification sequences in the carpus of three species of porpoises based on the $(\mathrm{a}-\mathrm{c})$ juvenile and (d-f) adult carpus morphologies-Harbor porpoise: (a) GM 96-01 (Dawson, 2003) and (d) USNM 550312; vaquita: (b) IBUNAM 26556 (Ortega-Ortiz et al., 2000) and (e) USNM 910313-1; and Burmeister's porpoise: (c) USNM 550241 and (f) USNM 395751. Scaphoid (s), lunate (l), cuneiform (c), trapezoid (t), and unciform (u) are labelled. Carpal elements are shaded black; other forelimb elements are shaded gray. Roman numerals indicate metacarpal number. Not to scale.

total length) displayed an additional carpal element, the unciform, in distal row in only the left manus (Figures $2 \mathrm{c} \& \mathrm{~d}$ ).

\section{Metacarpals and Phalanges}

Vaquita specimens ossified five metacarpals and displayed a maximum phalangeal formula of 1-98-4-2. In adult taxa, metacarpals I, II, and IV were rectangular in shape (Figures $2 \& 3 \mathrm{e}$ ), metacarpal III usually displayed a distocaudal projection indicating the presence of a supernumary digit (a characteristic of this taxon), and metacarpal V was triangular. Phalangeal diaphyses were either rectangular or ovoid. Digit I had only a single triangle shaped phalanx, and digit II had the most phalanges. Depending on sex, either the first two or three phalanges of this digit were rectangular in shape, while the distal phalanges were ovoid (Figure 2). Digit III had the same pattern, but with 
fewer phalanges. In some specimens, the first phalanx of digit IV was roughly rectangular, but distal phalanges were ovoid.

Patterns of metacarpal and phalangeal epiphyseal fusion between the sexes were highly disparate (Figures $2 \& 4$ ). In males, although some variation was documented, a general trend in ossification led to the ossification of the epiphyses of metacarpals I and II (Figure 4a through d). In all specimens at age 9, the proximal epiphysis of metacarpal I was completely ankylosed, while the distal epiphysis was partially ankylosed. By age 16, both the proximal and distal epiphyses of metacarpal I were fully ankylosed. Only the proximal epiphysis of metacarpal II was ankylosed at approximately $13 \mathrm{y}$ of age (Figure $4 \mathrm{~b}$ through d).

Ossification of the phalangeal epiphyses of males also displayed individual variation, but it was limited to the first phalanx of digit II (Figure 4a through d). Ankylosis of the proximal epiphysis

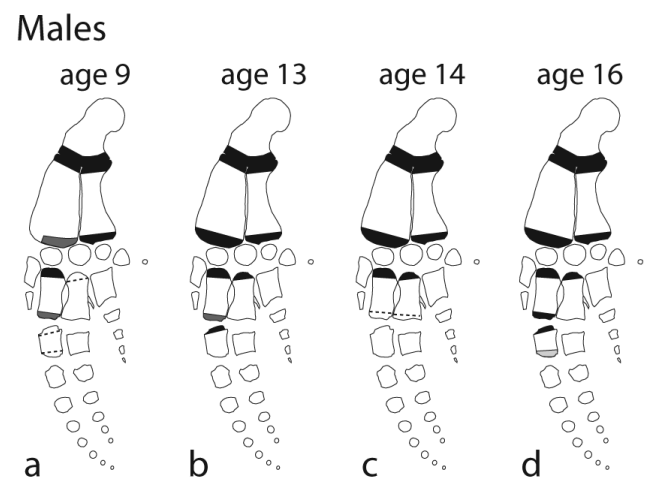

\section{Females}

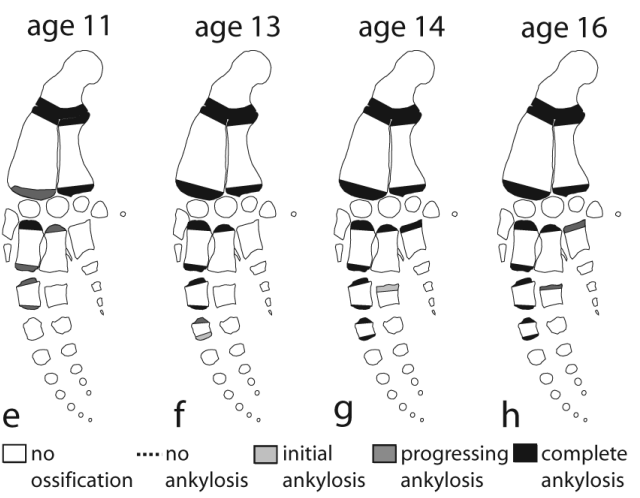

Figure 4. Schematic of ankylosis in the epiphyses of the vaquita flipper and associated ages in years for males and females; shading of the epiphyses indicates Stage 0, epiphyses unossified, not outlined; Stage 1, no ankylosis, dashed line; Stage 2, initial ankylosis, light gray; Stage 3, progressing ankylosis, dark gray; and Stage 4, complete ankylosis, black (modified from Galatius et al., 2006). Not to scale. was complete by age 16 , and the distal epiphysis was only partially fused. In this limited sample of known-age male flippers $(n=5)$, none showed epiphyseal ossification of other phalanges (Figure 4a through d).

Radiographs of known-age females taken from specimens aged at 11 to $16 \mathrm{y}$, showed greater numbers of ossified epiphyses and increased levels of ankylosis as compared to males of equivalent ages (Figure 4e through h). Females ossified and ankylosed the proximal epiphyses of metacarpals II through IV. No ossification was seen in the epiphyses of metacarpals I or V. At age 11 , the proximal epiphysis of metacarpal II was fully ankylosed, while the distal epiphysis is only partially ankylosed. By age 13, both epiphyses of metacarpal II were fully ossified. Only the proximal epiphysis of metacarpal III ossified in females in this sample, although its degree of ankylosis to the diaphysis varied. This epiphysis was mostly ankylosed by $11 \mathrm{y}$ of age (Figure 4e), and it was fully ankylosed by 13 y (Figure 4f). Unlike male vaquitas, the females fused their proximal epiphysis with the diaphysis of metacarpal IV (Figure $4 \mathrm{~g}$ $\& \mathrm{~h})$.

Phalangeal epiphyseal ossification of the female vaquitas spanned the proximal elements of digits II and III, and no phalanges displayed ossified epiphyses in digits I, IV, or V (Figure 4e through h). In digit II, phalanges 1 and 2 displayed ossified epiphyses. Both epiphyses of phalanx 1 were partially ankylosed by $11 \mathrm{y}$, and fully ankylosed at $13 \mathrm{y}$ of age. The proximal and distal epiphyses of phalanx 2 were partially ankylosed at $13 \mathrm{y}$, and fully ankylosed at $14 \mathrm{y}$ of age. The first phalanx of digit III began ossifying at $14 \mathrm{y}$ of age, and complete ankylosis was not observed (Figure $4 \mathrm{f}$ through h).

\section{Discussion}

The Unique Carpus of the Vaquita

Compared to its sister taxon, the Burmeister's porpoise and species of more distantly related porpoises ( $P$. dioptrica, $P$. phocoena, Phocoenoides dalli, and N. phocoenoides) (Fajardo-Mellor et al., 2006; Lambert, 2008), the vaquita has a similar carpal arrangement, with the proximal row consisting of three ossified elements (i.e., scaphoid, lunate, and cuneiform) (Figures $3 \& 5$ ). However, the vaquita differs from these taxa in distal carpal row element number and shape. Vaquitas are autapomorphic among porpoises by typically possessing only three, and in more rare cases four, ossified carpal elements, while all other phocoenids possess five elements (divided into two rows with three proximal and two distal elements). Vaquitas are unique in that they typically lack cartilaginous 


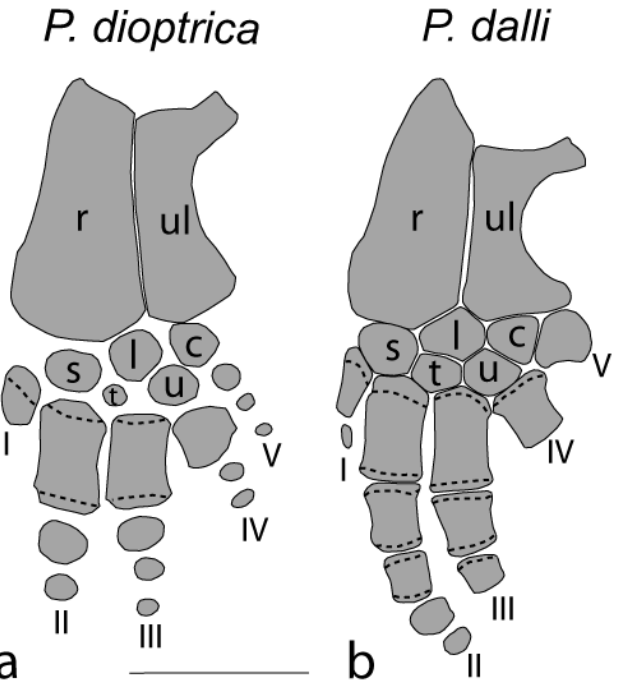

Figure 5. Manus ossification in porpoises: (a) spectacled porpoise (RNP 1245) and (b) Dall's porpoise (LACM 43473). Dashed lines indicate ossified epiphyses. Scale bar is $5 \mathrm{~cm}$.

anlagen for carpal elements in the distal row. Therefore, elements of the proximal row articulate with the proximal epiphyses of the metacarpals (Figures $2 \& 3 \mathrm{e}$ ). This unusual articulation resembles the juvenile morphology of other phocoenid taxa.

Besides ossifying a greater number of differently shaped carpals, the harbor porpoise also displays a different ossification pattern of the carpal elements. Carpal ossification proceeds in a cranial-to-caudal direction, beginning with the proximal (scaphoid and lunate) and distal (unciform) rows (Figure 3) (Dawson, 2003). The trapezoid then ossifies. Finally, the cuneiform is the last carpal to ossify (Figure 2a), and it may be absent in some adults (Dawson, 2003). Contrary to this pattern of carpal ossification, radiographs of the vaquita carpus (Ortega-Ortiz et al., 2000) showed that ossification proceeded in a caudal-to-cranial direction with the cuneiform and lunate beginning ossification before the scaphoid (Figure 3).

Juvenile specimens of the Burmeister's porpoise (USNM 550241) and harbor porpoise (Dawson, 2003; Gol'din, 2004) display rounded carpal elements that are almost identical in morphology to those seen in adult vaquitas (Figure 3). All adult non-vaquita phocoenids displayed angular articular facets along the carpal element margins (Figure $3 \mathrm{~d} \& \mathrm{f}$ ). Compared to other phocoenids, the vaquita is therefore autapomorphic in its retention of rounded rather than angular carpals as an adult. Furthermore, because rounded carpals are displayed in only immature non-vaquita phocoenids, the rounded carpals of the adult vaquita are considered an example of a paedomorphic morphology in the manus of this taxon.

Metacarpal and Phalangeal Patterns of Ossification Small-bodied delphinid cetaceans usually display rectangular-shaped metacarpal diaphyses of all but the distal-most phalanges (Calzada \& Aguilar, 1996; DiGiancamillo et al., 1998), while no epiphyses are found in the large-bodied orca (Figure 1c). The adult harbor porpoise retains several rounded and delta-shaped phalanges as a result of delayed perichondral ossification relative to delphinid cetaceans (Dawson, 2003). Compared to the harbor porpoise (Dawson, 2003), adult vaquitas have more ovoid elements. Adult vaquitas displayed ovoid phalanges in digits I and $\mathrm{V}$ as well as in the distal phalanges of digits II through IV (Figure 2). Therefore, both the harbor porpoise and vaquita display a paedomorphic phalangeal shape relative to delphinid cetaceans (Figures 1 \& 2).

Regarding epiphyseal ossification, studies have shown that harbor porpoise ossification patterns are paedomorphic relative to that of delphinid cetaceans in that dolphins ossify a greater number of phalangeal epiphyses (Figure 1a \& b) (Dawson, 2003; Gol'din, 2004; Galatius et al., 2006). The striped dolphin ossifies proximal and distal phalangeal epiphyses of all but the distal-most phalanges, while the harbor porpoise lacks epiphyseal ossification in the phalanges of digits I and V, and along the distal phalanges of digits II through IV (Figure 1) (Galatius et al., 2006). However, no ossified epiphyses were documented in Orcinus (Figure 1c). Contrary to both the small-bodied delphinid and harbor porpoise epiphyseal morphologies, the vaquita had fewer ossified epiphyses. The greatest numbers of ossified epiphyses were observed in adult female vaquitas (Figure $4 \mathrm{~g} \& \mathrm{~h})$. In this study, only females displayed ossification along the epiphyses of metacarpals II through IV, the first two phalanges of digit II, and the first phalanx of digit III. Moreover, compared to other porpoise taxa (see Figure $5 ; P$. dioptrica and $P$. dalli), female vaquitas also display fewer ossified epiphyses. Taken together, it appears that even the advanced degree of ossification displayed in the female vaquita manus is paedomorphic relative to non-Orcinus delphinid cetaceans and at least three phocoenid taxa (Figures $1 \& 5$; P. phocoena, P. dioptrica, and P. dalli).

\section{Patterns of Sexual Dimorphism}

Sexual dimorphism was found in the numbers of ossified metacarpal and phalangeal epiphyses between male and female vaquitas (Figure 4). Radiographs of known age males showed fewer 
numbers of ossified epiphyses and decreased levels of ankylosis compared to females of equivalent ages. Whereas females had ossified epiphyses of three metacarpals, several phalanges of digit II, and the first phalanx of digit III, males had ossified only epiphyses of two metacarpals and the first phalanx of digit II. Moreover, compared to females, male vaquitas were slower to completely ossify these epiphyses. Therefore, female vaquitas both ossified their elements more quickly and completely relative to males, and all males observed in this study retained a juvenile state of manus ossification relative to female vaquitas, indicating the presence of sexually dimorphic paedomorphosis in males.

Sexual dimorphism among phocoenids is not unique; female harbor porpoises exhibit a more rapid growth rate of certain body parts (McLellan et al., 2002) as well as a prolonged period of body growth and greater body sizes compared to their male counterparts (Galatius et al., 2006). Female harbor porpoises exhibit faster growth rates of the heart and organs that assist in the digestion, absorption, and transport of lipid-rich prey (e.g., liver, mesenteric lymph node, and intestines; McLellan et al., 2002). Alternatively, in male harbor porpoises, the locomotor musculature and pelvic bones grow more quickly relative to females and are related to the need for intensive swimming associated with gaining reproductive access to females. The accelerated growth rates of viscera in female harbor porpoises assists in early reproduction and development of relatively large offspring as the larger and more mature viscera will support higher rates of prey consumption (McLellan et al., 2002). This is essential for females as they do not rely on blubber for energy during lactation (Koopman, 1998). McLellan et al. (2002) attributed the increased growth rate and resultant larger heart of female harbor porpoises to the necessity of increased blood volume associated with pregnancy. Variation in both the soft tissue organs that experience allometric growth as well as the duration of total body growth has created sexual dimorphism in harbor porpoises. These changes are associated with a decrease in the time to sexual maturity and increased reproductive fitness (e.g., increasing available metabolic energy and allowing for increased blood volume).

Although male harbor porpoises display a shorter period of body growth and reach sexual maturity sooner, their digit morphologies remain paedomorphic relative to their female cohorts. Female harbor porpoises continue limb development after the age of $6 \mathrm{y}$, while males experienced a relative cessation in limb skeletal development rather than an accelerated maturation (Galatius et al., 2006).
The pattern of dimorphism documented in the vaquita is similar to that of the harbor porpoise in that males display fewer ossified and ankylosed metacarpal and phalangeal epiphyses compared to females (Figures $2 \& 4$ ). However, we are unable to resolve whether males display a faster growth rate prior to $9 \mathrm{y}$ of age because our sample size is skewed with the manus morphology known for males only between the ages of 9 and $16 y$.

\section{Conclusion}

This study examined morphological patterns and ossification rates of a rare porpoise, the vaquita, based on osteological and radiographical images of specimens. Compared to other porpoise taxa, the vaquita has fewer ossified carpal elements, and these elements display a paedomorphic morphology in that they are rounded rather than angular. Furthermore, relative to delphinid cetaceans (except $O$. orca), both the vaquita and the harbor porpoise display a greater number of rounded phalangeal diaphyses, indicating paedomorphosis. Lastly, compared to some porpoise taxa, vaquitas had fewer ossified phalangeal epiphyses. Taken together, these data indicate that the vaquita is a unique cetacean in that it displays four paedomorphic morphologies when compared to closely related taxa: (1) fewer numbers of ossified carpal elements; (2) rounded, rather than angular, carpal elements; (3) a greater number of distal phalanges that are ovoid in shape; and (4) fewer ossified metacarpal and phalangeal diaphyses.

Heterochronic delays in skeletal development within the forelimbs of cetaceans appear to be a common trait. Several non-delphinid cetaceans display poorly ossified carpal elements and metacarpal and phalangeal epiphyses, and within the Delphinidae, only the large-bodied, $O$. orca displays a paedomorphic manus shape in its lack of ossified carpal elements and metacarpophalangeal epiphyses (Figure 1c). Most porpoises, compared to delphinids, display paedomorphic manus morphologies, but the vaquita is autapomorphic in its degree of paedomorphic morphologies. These data offer some insight into the skeletal development of the vaquita; however, little is known of forelimb development prior to $9 \mathrm{y}$ of age. That male vaquitas experience a faster skeletal growth rate is certainly suggested by our dataset, but this requires further investigation.

A larger question is what altered developmental pathways led to these paedomorphic manus morphologies. Within the vaquita, the manus, diaphyseal, and epiphyseal ossification is halted very early in development, suggesting changes to the Sox9 pathway responsible for endochondral ossification (Cohn \& Bright, 1999). Since hyperphalangy is 
well-documented in the digits of porpoises, this suggests that proximal-distal limb growth is not altered, and mesenchymal precursors of digital elements are deposited as in other cetaceans (see Cooper et al., 2007a). Differentiation from mesenchymal condensations to cartilaginous anlagen also appears to be consistent with other cetaceans. However, endochondral ossification is delayed or absent both within the diaphyses of the digits as well as epiphyseal ossification and fusion to the diaphyses.

\section{Acknowledgments}

We thank Cheryl Knudson, Burt Rosenman, Mike Selby, and Ronald B. Cooper for providing useful comments on this manuscript. We also appreciate reviews of this manuscript provided by Annalisa Berta, Jeanette A. Thomas, E. M. Walter, and an anonymous reviewer. We thank James Mead, Charley Potter, and Dee Allen for access and assistance with osteological and radiographical images of porpoises, and Annalisa Berta for use of the Orcinus specimen. We also acknowledge the following individuals who allowed us collection access: Larry Barnes, John Heyning, and Dave Janiger (LACM, Los Angeles, CA); Jim Mead, Charlie Potter, and Dee Allen (USNM, Washington, DC); and Natalie Goodall (Museo Acatushún, Tierra del Fuego, Argentina).

Funding for part of this study was awarded to LM from Sigma Xi, Phi Beta Delta Scholarship, and the San Diego State University International Travel Scholarship.

\section{Literature Cited}

Barnes, L. G. (1985). Evolution, taxonomy and antitropical distribution of the porpoises (Phocoenidae, Mammalia). Marine Mammal Science, 1, 149-165.

Bininda-Emonds, O. R. P., Jeffery, J. E., Sánchez-Villagra, M. R., Hanken, J., Colbert, M., Pieau, C., et al. (2007). Forelimb-hindlimb developmental timing changes across tetrapod phylogeny. BMC Evolutionary Biology, 7, 182-189.

Brownell, R. L., Jr. (1983). Phocoena sinus. Mammalian Species, 198, 1-3.

Calzada, N., \& Aguilar, A. (1996). Flipper development in the Mediterranean striped dolphin (Stenella coeruleoalba). Anatomical Record, 245, 708-714.

Cohn, M. J., \& Bright, P. E. (1999). Molecular control of vertebrate limb development, evolution and congenital malformations. Cell and Tissue Research, 296, 3-17.

Cooper, L. N., Berta, A., Dawson, S. D., \& Reidenberg, J. S. (2007a). Evolution of hyperphalangy and digit reduction in the cetacean manus. Anatomical Record, 290, 654-672.

Cooper, L. N., Dawson, S. D., Reidenberg, J. S., \& Berta, A. (2007b). Neuromuscular anatomy and evolution of the cetacean forelimb. Anatomical Record, 290, 11211137.

Dawson, S. D. (2003). Patterns of ossification in the manus of the harbor porpoise (Phocoena phocoena): Hyperphalangy and delta-shaped bones. Journal of Morphology, 258, 200-206.

DiGiancamillo, M., Rattegni, G., Podest, M., Cagnolaro, L., Cozzi, B., \& Leonardi, L. (1998). Postnatal ossification of the thoracic limb in striped dolphins (Stenella coeruleoalba) (Meyen, 1883) from the Mediterranean Sea. Canadian Journal of Zoology, 76, 1286-1293.

Fajardo-Mellor, L., Berta, A., Brownell, R. L., Jr., Boy, C. C., \& Goodall, R. N. P. (2006). The phylogenetic relationships and biogeography of true porpoises (Mammalia: Phocoenidae) based on morphological data. Marine Mammal Science, 22, 910-932.

Fedak, T. J., \& Hall, B. K. (2004). Perspectives on hyperphalangy: Patterns and processes. Journal of Anatomy, 204, 151-163.

Flower, W. H. (1885). Introduction to the osteology of Mammalia (3rd ed.). London: MacMillan and Co. 382 pp.

Galatius, A., Andersen, M-B. E. R., Haugan, B., Langhoff, H. E., \& Jespersen, Å. (2006). Timing of epiphyseal development in the flipper skeleton of the harbour porpoise (Phocoena phocoena) as an indicator of paedomorphosis. Acta Zoologica (Stockholm), 87, 77-82.

Galis, F., Wagner, G. P., \& Jockusch, E. L. (2003). Why is limb regeneration possible in amphibians but not in reptiles, birds and mammals? Evolution and Development, 5(2), 208-220.

Geisler, J. H., \& Uhen, M. D. (2003). Morphological support for a close relationship between hippos and whales. Journal of Vertebrate Paleontology, 23, 991-996.

Gingerich, P. D., ul Haq, M., Zalmout, I. S., Khan, I. H., \& Malkani, M. S. (2001). Origin of whales from early artiodactyls: Hands and feet of Eocene Protocetidae from Pakistan. Science, 293, 2239-2242.

Gol'din, P. E. (2004). Postnatal growth and ossification of the forelimb skeleton in the harbour porpoise (Phocoena phocoena (Linnaeus, 1758) from the Sea of Azov and the Black Sea (Uchenye Zapiski (Science Reports), V.I.). Vernadsky Taurida National University Series, 17(56), 2, 66-81. [In Russian]

Gomez, C., Özbudak, E. M., Wunderlich, J., Baumann, D., Lewis, J., \& Pouquié, O. (2008). Control of segment number in vertebrate embryos. Nature, 454, 335-339.

Hohn, A. A., Read, A. J., Fernandez, S., Vidal, O., \& Findley, L. F. (1996). Life history of the vaquita, Phocoena sinus (Phocoenidae, Cetacea). Journal of Zoology London, 239, 235-251.

Howell, A. B. (1930). Aquatic mammals: Their adaptations to life in water. Springfield, IL: Charles C. Thomas. 338 pp.

International Committee on Veterinary Gross Anatomical Nomenclature. (2005). Nomina anatomica veterinaria (5th ed.). Gent, Belgium: World Association of Anatomists. 
Jaramillo-Legorreta, A., Rojas-Bracho, L., Brownell, R. L., Jr., Read, A. J., Reeves, R. R., Ralls, K., et al. (2007). Saving the vaquita: Immediate action, not more data. Conservation Biology, 21, 1653-1655.

Koopman, H. N. (1998). Topographical distribution of the blubber of harbor porpoises (Phocoena phocoena). Journal of Mammalogy, 79, 260-270.

Lambert, O. (2008). A new porpoise (Cetacea, Odontoceti, Phocoenidae) from the Pliocene of the North Sea. Journal of Vertebrate Paleontology, 28, 863-872.

Magatagan, M. D., Boyer, E. H., \& Villa-Ramírez, B. (1984). Revisión del estado que guarda Phocoena sinus Norris and McFarland y descripción de tres nuevos ejemplares. [Revision of the status of Phocoena sinus Norris and McFarland and description of three new specimens]. Anales del Instituto de Biología Universidad Nacional Autónoma de México, Série Zoologia, 55, 271-294.

McLellan, W. A., Koopman, H. N., Rommel, S. A., Read, A. J., Potter, C. W., Nicolas, J. R., et al. (2002). Ontogenetic allometry and body composition of harbour porpoises (Phocoena phocoena, L.) from the western North Atlantic. Journal of the Zoological Society London, 257, 457-471.

Morell, V. (2008). Can the vaquita be saved? Science, 321, 767.

Noble, B. A., \& Fraser, F. C. (1971). Description of a skeleton and supplementary notes on the skull of a rare porpoise Phocoena sinus Norris and McFarland 1958. Journal of Natural History, 5, 447-464.

Ortega-Ortiz, J. G. (1993). Descripción osteológical de la aleta pectoral de la vaquita Phocoena sinus (Cetacea: Phocoenidae) [Osteologial description of the pectoral fin of the vaquita Phocoena sinus (Cetacea: Phocoenidae)]. Bachelor of Science thesis, Universidad Nacional Autónoma de México, México. 46 pp.

Ortega-Ortiz, J. G., Villa-Ramírez, B., \& Gersenowies, J. R. (2000). Polydactyly and other features of the manus of the vaquita (Phocoena sinus). Marine Mammal Science, 16, 277-286.

Richardson, M. K. (1995). Heterochrony and the phylotypic period. Developmental Biology, 172, 412-421.

Richardson, M. K., \& Oelschläger, H. H. A. (2002). Time, pattern and heterochrony: A study of hyperphalangy in the dolphin embryo flipper. Evolution and Development, 4, 435-444.

Richardson, M. K., Hanken, J., Gooneratne, M. L., Pieau, C., Raynaud, A., Selwood, L., et al. (1997). There is no highly conserved embryonic stage in vertebrates: Implications for current theories of evolution and development. Anatomy and Embryology, 196, 91-106.

Rojas-Bracho, L., Reeves, R. R., \& Jaramillo-Legoretta, A. (2006). Conservation of the vaquita Phocoena sinus. Mammalian Review, 36(3), 179-216.

Rosel, P. E., Frantzis, A., Lockyer, C., \& Komnenou, A. (2003). Source of Aegean Sea harbour porpoises. Marine Ecology Progress Series, 247, 257-261.

Schlosser, G. (2001). Using heterochrony plots to detect the dissociated coevolution of characters. Journal of Experimental Zoology Part B: Molecular and Developmental Evolution, 291, 282-304.

Sears, K. E., Behringer, R. R., Rasweiler IV, J. J., \& Niswander, L. A. (2006). Development of bat flight: Morphologic and molecular evolution of bat wing digits. Proceedings of the National Academy of Sciences, 103, 6581-6586.

Sedmera, D., Misek, I., \& Klima, M. (1997). On the development of cetacean extremities: II. Morphogenesis and histogenesis of the flippers in the spotted dolphin (Stenella attenuata). European Journal of Morphology, 35(2), 117-123.

Smith, G. J. D., Browne, K. W., \& Gaskin, D. E. (1976). Functional myology of the harbour porpoise, Phocoena phocoena (L.). Canadian Journal of Zoology, 54, 716729.

Smith, K. K. (2003). Time's arrow: Heterochrony and the evolution of development. International Journal of Developmental Biology, 47, 613-621.

Taylor, B., \& Rojas-Bracho, L. (1999). Examining the risk of inbreeding depression in a naturally rare cetacean, the vaquita (Phocoena sinus). Marine Mammal Science, 15, 1004-1028.

Thewissen, J. G. M., Williams, E. M., Roe, L. J., \& Hussain, S. T. (2001). Skeletons of terrestrial cetaceans and the relationship of whales to artiodactyls. Nature, 413, 277 281.

Thewissen, J. G. M., Cooper, L. N., Clementz, M. T., Bajpai, S., \& Tiwari, B. N. (2007). Whales originated from aquatic artiodactyls in the Eocene epoch of India. Nature, 450, 1190-1194.

Torre-Cosio, J. (1995). Descripción del esqueleto, dimorfismo sexual y crecimiento alometrico en el craneo de la vaquita, Phocoena sinus (Cetacea: Phocoenidae) [Description of the skeleton, sexual dimorphism and allometric growth in the cranium of the vaquita (Cetacea: Phocoenidae)]. Master of Science thesis, Instituto Tecnológico y de Estudios Superiores de Monterey-Campus Guaymas. 183 pp.

Villa-Ramírez, B., Peralta-Perez, M., \& Delgada-Estrella, A. (1996). Description of the third metacarpal axial process in the pectoral fins of Phocoena sinus. In H. H. Genoways \& R. J. Baker (Eds.), Contributions in mammalogy: A memorial volume honoring Dr. J. Knox Jones, Jr. (pp. 205-208). Lubbock: Museum of Texas Tech University.

Woodward, B. L., Winn, J. P., \& Fish, F. E. (2006). Morphological specializations of baleen whales associated with hydrodynamic performance and ecological niche. Journal of Morphology, 267, 1284-1294. 
Appendix. Radiographs and osteological specimens examined at the Instituto Tecnológico y de Estudios Superiores de Monterey, Guaymas, Mexico (ITESM), the Smithsonian Institution (USNM), the San Diego Natural History Museum (SDNHM), the Los Angeles County Museum (LACM), and the R. Natalie P. Goodall Foundation at the Museo Acatushún, Tierra del Fuego, Argentina (RNP); figured specimens are indicated with an $(*)$.

\begin{tabular}{|c|c|c|c|c|c|}
\hline Taxon & Institution number & Data type & Age & Sex & Body length $(\mathrm{cm})$ \\
\hline \multicolumn{6}{|l|}{ Vaquita porpoise $(n=18)$} \\
\hline Phocoena sinus & ITESM 860517-01-9 & radiographic & N/A & N/A & 110.0 \\
\hline Phocoena sinus & ITESM 900227 & radiographic & N/A & female & 109.3 \\
\hline Phocoena sinus & ITESM 910304 & radiographic & 2 & female & 128.7 \\
\hline Phocoena sinus & ITESM 850313-02-27 & radiographic & 11 & female & 135.0 \\
\hline Phocoena sinus* & ITESM 910313-1 & radiographic & 13 & female & 139.7 \\
\hline Phocoena sinus & ITESM 850313-01-26 & radiographic & 14 & female & 135.0 \\
\hline Phocoena sinus & ITESM 900408 & radiographic & 16 & female & 135.0 \\
\hline Phocoena sinus & ITESM 850314-01-03 & radiographic & N/A & male & 106.9 \\
\hline Phocoena sinus & ITESM 910312-1 & radiographic & N/A & male & 109.1 \\
\hline Phocoena sinus & ITESM 900526 & radiographic & N/A & male & 113.7 \\
\hline Phocoena sinus & ITESM 910207 & radiographic & N/A & male & 116.0 \\
\hline Phocoena sinus & ITESM 910521 & radiographic & N/A & male & 125.3 \\
\hline Phocoena sinus & ITESM 900519 & radiographic & N/A & male & 127.0 \\
\hline Phocoena sinus* & ITESM 900421 & radiographic & 9 & male & 142.2 \\
\hline Phocoena sinus & ITESM 910313-3 & radiographic & 13 & male & 144.0 \\
\hline Phocoena sinus & ITESM 900412 & radiographic & 14 & male & 131.8 \\
\hline Phocoena sinus & ITESM 850313-04-24 & radiographic & 16 & male & 134.5 \\
\hline Phocoena sinus & ITESM 910226 & radiographic & 16 & male & 128.3 \\
\hline \multicolumn{6}{|l|}{ Burmeister's porpoise $(n=4)$} \\
\hline Phocoena spinipinnis* & USNM 395752 & osteological & -- & -- & -- \\
\hline Phocoena spinipinnis & USNM 395751 & osteological & -- & -- & -- \\
\hline Phocoena spinipinnis & USNM 395380 & osteological & N/A & N/A & N/A \\
\hline Phocoena spinipinnis* & USNM 550241 & radiographic & -- & -- & -- \\
\hline \multicolumn{6}{|l|}{ Harbor porpoise $(n=1)$} \\
\hline Phocoena phocoena & USNM 550312 & radiographic & -- & female & 158.0 \\
\hline \multicolumn{6}{|l|}{ Dall's porpoise $(n=3)$} \\
\hline Phocoenoides dalli & SDNHM 20270 & osteological & -- & male & -- \\
\hline Phocoenoides dalli & USNM 504417 & radio \& osteo & -- & male & -- \\
\hline Phocoenoides dalli* & LACM 43473 & osteological & N/A & N/A & N/A \\
\hline \multicolumn{6}{|l|}{ Spectacled porpoise $(n=2)$} \\
\hline Phocoena dioptrica & RNP 0658 & osteological & 6 & female & 203.5 \\
\hline Phocoena dioptrica* & RNP 1245 & osteological & 8 & N/A & N/A \\
\hline \multicolumn{6}{|l|}{ Finless porpoise $(n=2)$} \\
\hline Neophocaena phocaenoides & USNM 240001 & osteological & N/A & female & N/A \\
\hline Neophocaena phocaenoides & USNM 240002 & osteological & N/A & male & N/A \\
\hline
\end{tabular}

